\title{
Change in viable bacterial count during preservation of milk derived from dairy cows with subclinical mastitis and its relationship with antimicrobial components in milk
}

\author{
Keiichi HISAEDA ${ }^{1)}$, Tomoko KOSHIISHI ${ }^{2)}$, Masako WATANABE ${ }^{3)}$, Hajime MIYAKE ${ }^{2)}$, Yukinori YOSHIMURA ${ }^{4)}$ and \\ Naoki ISOBE ${ }^{4) *}$ \\ ${ }^{1)}$ Nanyo Core Veterinary Clinic, Ehime P.F.A.M.A.A. Seiyo, Ehime 797-1211, Japan \\ ${ }^{2)}$ Oozu Veterinary Clinic, Ehime P.F.A.M.A.A. Oozu, Ehime 795-0064, Japan \\ 3) Touyo Veterinary Clinic, Ehime P.F.A.M.A.A. Saijo, Ehime 799-1312, Japan \\ ${ }^{4)}$ Graduate School of Biosphere Science, Hiroshima University, Higashi-Hiroshima, Hiroshima 739-8528, Japan
}

(Received 28 January 2016/Accepted 12 April 2016/Published online in J-STAGE 24 April 2016)

ABSTRACT. The objectives of the present study were to investigate the change in the number of viable pathogens during preservation of milk obtained from cows with subclinical mastitis and the association between the decreasing ratio of viable bacteria during preservation and the somatic cell count (SCC) and the values of lingual antimicrobial peptide (LAP), lactoferrin (LF) and lactoperoxidase (LPO). After preservation of milk at room temperature for $0,0.5,1,2,3,4$ and $5 \mathrm{hr}$, the bacterial colonies in the milk were counted to determine the number of colony forming units (CFUs). Fresh skim milk was used to determine the values of LAP, LPO and LF. Bacteria were not detected in $19.4 \%$ of milk samples, and this percentage increased up to $30 \%$ after $5 \mathrm{hr}$ of preservation. The number of Staphylococcus aureus and Streptococcus uberis in milk did not change significantly during the 5-hr incubation, whereas significant decreases were observed in the number of coliforms, coagulase-negative staphylococci, yeasts and Corynebacterium bovis. High SCC significantly decreased CFUs of $S$. aureus and yeast after preservation of milk for 4 to $5 \mathrm{hr}$. High LF concentration in milk was associated with decrease in CFU of $S$. aureus during 4-hr preservation. These results suggest that the viable counts of some pathogens in milk decreased during preservation at room temperature after collection, which may be attributed to the leukocytes and antimicrobial components present in milk.

KEY WORDS: dairy cow, milk, pathogen, preservation, somatic cell count

doi: 10.1292/jvms.16-0049; J. Vet. Med. Sci. 78(8): 1245-1250, 2016

Mastitis is an inflammation of the udder, typically caused by bacterial infection in bovine and other animals. It reduces milk production, consequently incurring economic losses for the dairy industry. Identification of causal bacteria is necessary to treat mastitis. Therefore, bacteriological examination of milk is important to determine the clinical treatment for mastitis. However, approximately $10-40 \%$ of milk samples collected from mastitic cows show "no significant bacterial growth" in routine clinical culture assays, the exact reason for which is currently unknown $[18,19]$. It could be attributed to infection caused by bacteria present in low numbers, without a reduction in the somatic cell count (SCC). Other influencing factors include the sampling procedure, treatment of milk samples, media used in the bacteriological examination, presence of pathogens below current detection thresholds or absence of bacteria at culture initiation; alternatively, the mastitis may be caused by non-bacterial microorganisms [7, 15]. Since the selection of antibiotics largely depends on the bacterial species infecting the milk, it is important to clarify why the milk tested negative for pathogens.

*Correspondence to: Isobe, N., Graduate School of Biosphere Science, Hiroshima University, Higashi-Hiroshima, 739-8528 Japan. e-mail: niso@hiroshima-u.ac.jp

(C) The Japanese Society of Veterinary Science

This is an open-access article distributed under the terms of the Creative Commons Attribution Non-Commercial No Derivatives (by-nc-nd) License $<$ http://creativecommons.org/licenses/by-nc-nd/4.0/>.
The innate immune function of the bovine mammary gland is highly developed in order to protect it from invading pathogens. Different antimicrobial components (one of the innate immune factors), such as lingual antimicrobial peptide (LAP), cathelicidins, lactoferrin (LF), lactoperoxidase (LPO) and S100 protein, are produced in mammary epithelial cells and leukocytes and secreted in milk $[6,8,9,11,20,24$, $26,27]$. Their concentrations in mastitic milk are higher than those in healthy milk $[4,10,13,16,26,27]$. LAP exhibited antimicrobial activity against gram-positive and -negative bacteria and fungi [23]. LF has antimicrobial activity against E. coli and Staphylococcus aureus (S. aureus) [14]. Milk LPO catalyzes, in the presence of hydrogen peroxide, the oxidation of thiocyanate ( $\mathrm{SCN}-$ ) to yield hypothiocyanite $(\mathrm{OSCN}-)$ and hypothiocyanous acid (HOSCN) [22]. These compounds are effective against staphylococci and E. coli [12].

The process from milking to culturing spans several hours, and it may be possible that the pathogens present in milk are killed by the antimicrobial components during this intervening period. However, the possibility of this phenomenon remains to be elucidated. Therefore, the objective of the present study was to investigate the change in the number of live pathogenic microbes during preservation of milk collected from udders of mastitic cattle, and the association between the number of viable pathogens and the SCC and the levels of LAP, LPO and LF. 


\section{MATERIALS AND METHODS}

Animals: In total, 62 Holstein Friesian cows (77 quarters; 2-38 weeks postpartum) grazed in 12 private dairy farms were included in the study. The cows were managed with tie stalls in 10 farms, a free barn in one farm and free stalls in one farm. This study was performed in accordance with the regulations of Hiroshima University Animal Research Committee.

Milk collection: The quarter milk was subjected to California Mastitis Test (CMT) before collection, and only CMT-positive milk was collected from cows with no clinical symptoms of mastitis. The SCC in milk was measured by a fluorescence optical somatic cell-measuring equipment (SomaScope Series; Milestone-General, Kawasaki, Japan). The CMT-positive milk with an SCC $>300,000 / \mathrm{m} l$ (indicative of subclinical mastitis) was used in the present study $(n=77)$. Milk fat was removed following centrifugation $(3,000 \times \mathrm{g}$, $15 \mathrm{~min}$ and $4^{\circ} \mathrm{C}$ ), and skim milk was frozen at $-20^{\circ} \mathrm{C}$ until the measurement of innate immune factors. The remaining mastitic milk was kept at 15 to $25^{\circ} \mathrm{C}$ for $0,0.5,1,2,3,4$ and $5 \mathrm{hr}$. Thereafter, $50 \mu \mathrm{l}$ of the milk was plated onto $5 \%$ sheep blood agar (BBL, Tokyo, Japan) and cultured at $37^{\circ} \mathrm{C}$ for $18-48 \mathrm{hr}$ to determine the count colony forming units (CFUs). S. aureus was identified by a positive coagulase test using rabbit serum (Usagi plasma EIKEN; EIKEN Chemical Co., Ltd., Tokyo, Japan). Streptococcus uberis (S. uberis) was identified using an identification kit (MIYARISAN Medicine manufacture Co., Ltd., Tokyo, Japan). Other pathogen identification was conducted in accordance with the law described elsewhere [7].

Measurement of innate immune factors: The concentration of LAP in skim milk was measured as previously described [11], LF concentration was measured by an ELISA quantification set, as per the manufacturer's protocol (Bethyl Laboratories, Inc., Montgomery, TX, U.S.A.), and LPO activity was determined as described [9].

Statistics: Nonparametric data were compared using the Kruskal-Wallis test and Friedman's test, while Dunnett's single diffusion and Bonferroni's single diffusion were used to compare the differences among groups with parametric data. Correlation analysis was performed using Spearman's rank correlation coefficient in case of nonparametric data, and Pearson's moment correlation analysis in case of parametric data. $P<0.05$ was considered statistically significant.

\section{RESULTS}

As shown in Table 1, S. uberis was detected in $10.4 \%$ of milk samples with high SCC, although more than $25 \%$ of the milk samples contained streptococci except for S. agalactiae and S. uberis (ST). Coliforms were observed in $14.2 \%$ of milk samples. $S$. aureus and coagulase-negative staphylococci (CNS), Yeast and Corynebacterium bovis (C. bovis) were also detected in less than $10 \%$ of milk samples.

In $19.4 \%$ of milk samples, no viable bacterial growth was noted just after collection. However, the percentage of milk samples without viable bacteria increased to $30 \%$ after pres-
Table 1. Pathogens derived from milk with high somatic cell count

\begin{tabular}{lc}
\hline \multicolumn{1}{c}{ Pathogen } & $\begin{array}{c}\text { Number (\%) of milk } \\
\text { samples }\end{array}$ \\
\hline Coliforms & $11(14.2)$ \\
Streptococcus uberis & $8(10.4)$ \\
ST & $20(25.9)$ \\
Staphylococcus aureus & $7(9.0)$ \\
Coagulase-negative staphylococci & $7(9.0)$ \\
Yeasts & $5(6.5)$ \\
Corynebacterium bovis & $4(5.1)$ \\
Not detected & $15(19.4)$ \\
Total & 77 \\
\hline
\end{tabular}

Milk samples were collected from 77 quarters in 62 Holstein Friesian cows.ST: streptococci except for S. agalactiae and $S$. uberis.

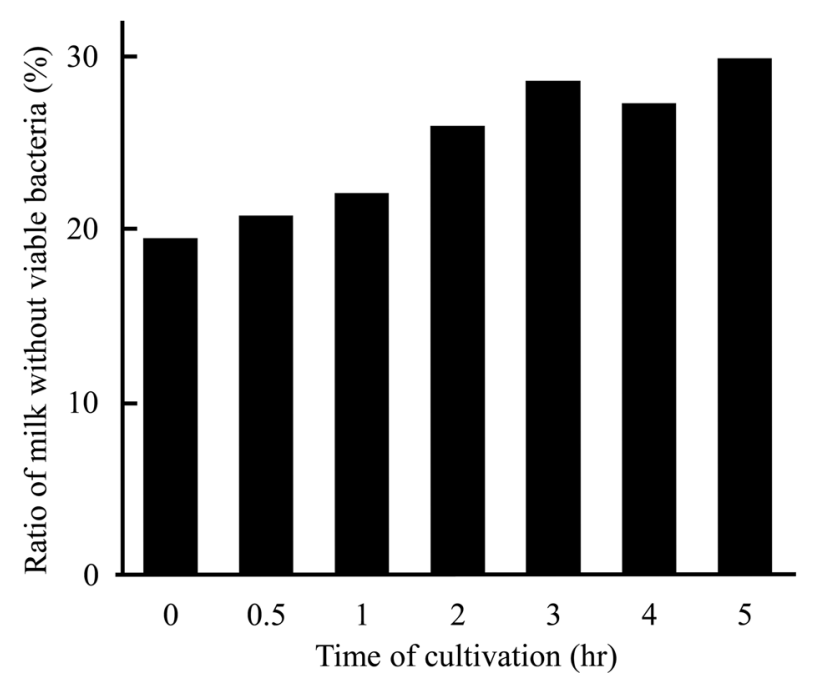

Fig. 1. Changes in the percentage of milk samples without viable bacteria in milk during preservation. Bars denote the percentage of milk samples without viable bacteria $(n=77)$.

ervation for $3-5 \mathrm{hr}$ (Fig. 1).

The changes in the CFUs of different pathogens in milk during preservation are shown in Figs. 2 and 3. The CFUs of coliforms tended to decrease during preservation and showed a significant decrease to $49 \pm 14 \%$ at $4 \mathrm{hr}$ (Fig. 2). In C. bovis, yeast and CNS, CFUs decreased significantly to less than $60 \%$ even at $30 \mathrm{~min}(47 \pm 9 \%, 45 \pm 16 \%$ and 61 $\pm 17 \%$, respectively) and continued to decrease thereafter, resulting in $<20 \%$ CFUs at $5 \mathrm{hr}(12 \pm 7 \%, 9 \pm 9 \%$ and 20 $\pm 11 \%$, respectively, Figs. 2 and 3 ). The CFUs of ST decreased significantly when milk was preserved for longer than $1 \mathrm{hr}$ (Fig. 3). The CFUs of $S$. uberis tended to decrease during preservation; however, no significant difference was observed. The CFUs of SA showed no significant reduction during preservation.

When the correlation among SCC, LAP and LF concentrations, and LPO activity was analyzed in all milk samples, 


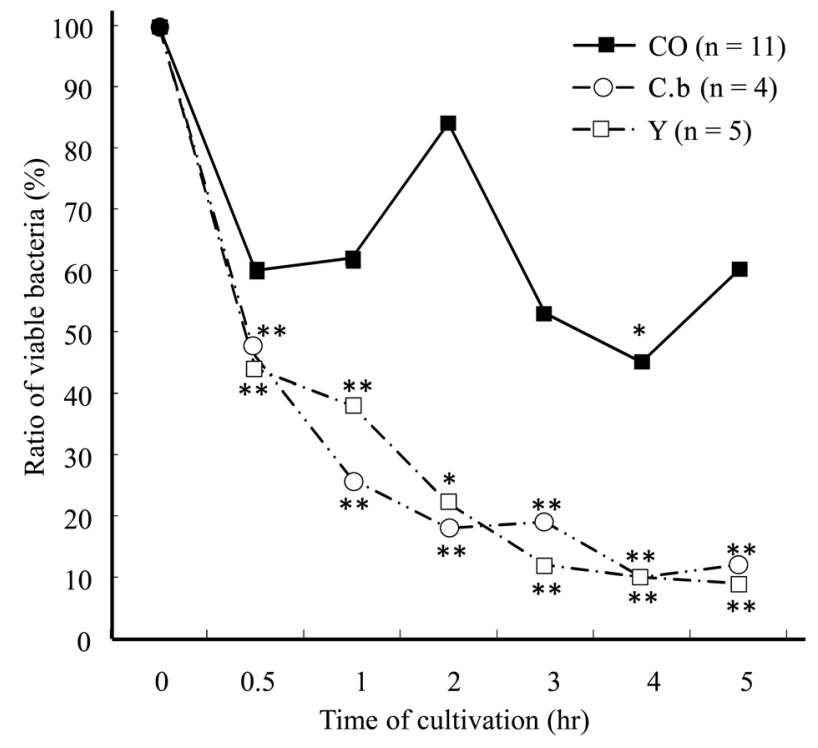

Fig. 2. Changes in the number of viable pathogens that decreased significantly during preservation. The vertical axis represents the ratio of viable pathogen number at each preservation time to the number at the onset of cultivation. CO: Coliforms, C.b: Corynebacterium bovis, Y: Yeasts *,**: Significant differences $v$ s. viable organism counts at $0 \mathrm{hr}(* * P<0.01, * P<0.05)$.

significant positive correlation was found between LAP and SCC ( $\mathrm{r}=0.232)$, LAP and LPO $(\mathrm{r}=0.255)$, and LPO and LF $(\mathrm{r}=0.54)$ (Table 2). The concentrations of LAP and LF and LPO activity in milk containing different pathogen species are shown in Fig. 4. LAP and LF concentrations did not significantly differ among different pathogenic species, although significantly higher LPO activity was found in milk containing yeast rather than coliforms.

To investigate whether the secretion of the innate immune factors is promoted by pathogens, the correlation between CFUs and the levels of innate immune factors in milk before preservation was analyzed (Table 3 ). We observed that only the CFUs of ST showed significant positive correlation to the SCC. In yeast and C. bovis, significant positive correlations were observed between CFUs and LAP, LF concentrations and LPO activity, but not between $C$. bovis and LPO activity. The CFUs of CNS showed a significant positive correlation to LPO activity.

To investigate whether innate immune factors are associated with the decrease in CFUs during milk preservation, the CFUs of pathogens after $4 \mathrm{hr}$ and $5 \mathrm{hr}$ of preservation were divided by those at $0 \mathrm{hr}$ (decreasing ratio), and their correlations to the levels of innate immune components were calculated (Table 4). In SA, high SCC and LF concentration decreased pathogen numbers at $4 \mathrm{hr}$, although LAP concentration increased it at $5 \mathrm{hr}$. The correlation between the SCC and decreasing ratio of yeast at $4 \mathrm{hr}$ was significantly negative, whereas a positive correlation between the SCC and decreasing ratio of CNS was observed at $4 \mathrm{hr}$ and $5 \mathrm{hr}$ of preservation. The decreasing ratio of $C$. bovis at $4 \mathrm{hr}$ was

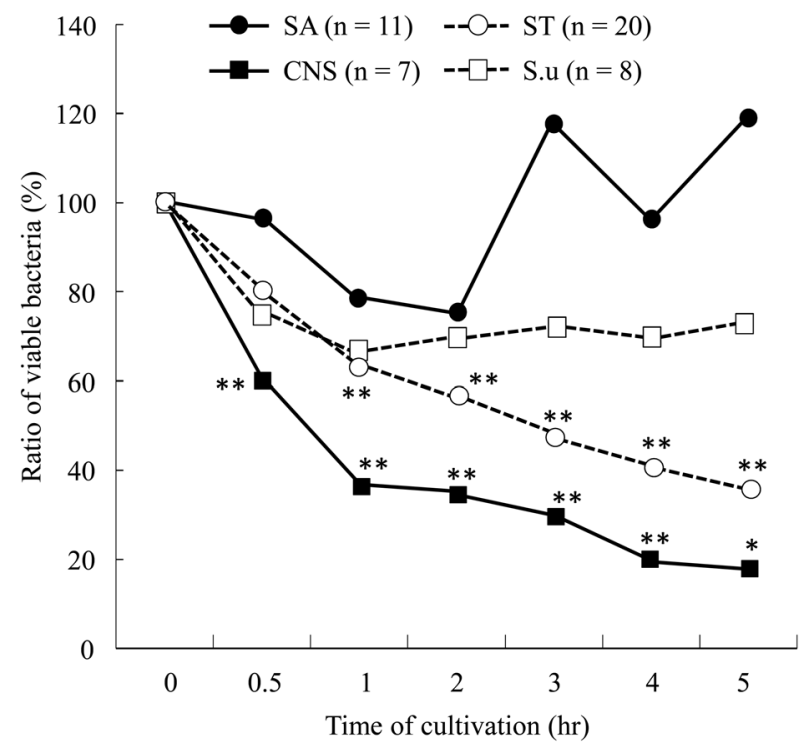

Fig. 3. Changes in the number of viable pathogens during preservation. The vertical axis represents the ratio of viable pathogen number at each preservation time to the number at the onset of cultivation. SA: Staphylococcus aureus, CNS: Coagulase-negative staphylococci, S.u.: Streptococcus uberis, ST: streptococci except for $S$. agalactiae and $S$. uberis. ***: Significant differences vs. viable arganism counts at $0 \mathrm{hr}(* * P<0.01, * P<0.05)$.

Table 2. Correlation coefficients among somatic cell count (SCC), lingual antimicrobial peptide (LAP), lactoperoxidase (LPO) or lactoferrin (LF) values in milk

\begin{tabular}{ccccc}
\hline items & SCC & LAP & LPO & LF \\
\hline SCC & - & & & \\
LAP & $0.23^{\text {a) }}$ & - & & \\
LPO & 0.16 & $0.26^{\text {a }}$ & - & \\
LF & 0.13 & -0.01 & $0.54^{\text {b) }}$ & - \\
\hline
\end{tabular}

Values are correlation coefficients. a) $P<0.05$; b) $P<0.01$ (statistically significant correlation between items).

found to be positively correlated to LAP concentration.

\section{DISCUSSION}

In the present study, ST were the most frequently isolated pathogens; this finding supports a previous report [17]. Although the milk was cultured immediately after collection, no CFUs were observed in about $19.4 \%$ of milk samples. This percentage of milk samples without CFUs increased up to $30 \%$ when the samples were preserved for more than $3 \mathrm{hr}$. However, the DNA of pathogens was detected in the milk by PCR, despite no growth being observed in the clinical culture system $[15,17]$. It was reported that milk with a high SCC contained a high concentration of antibacterial peptides [9-11, 26, 27]. Therefore, it is possible that the pathogens were killed by the leukocytes and/or innate immune factors present in the milk, resulting in decreased CFUs during its preservation after collection. Therefore, in the present study, 

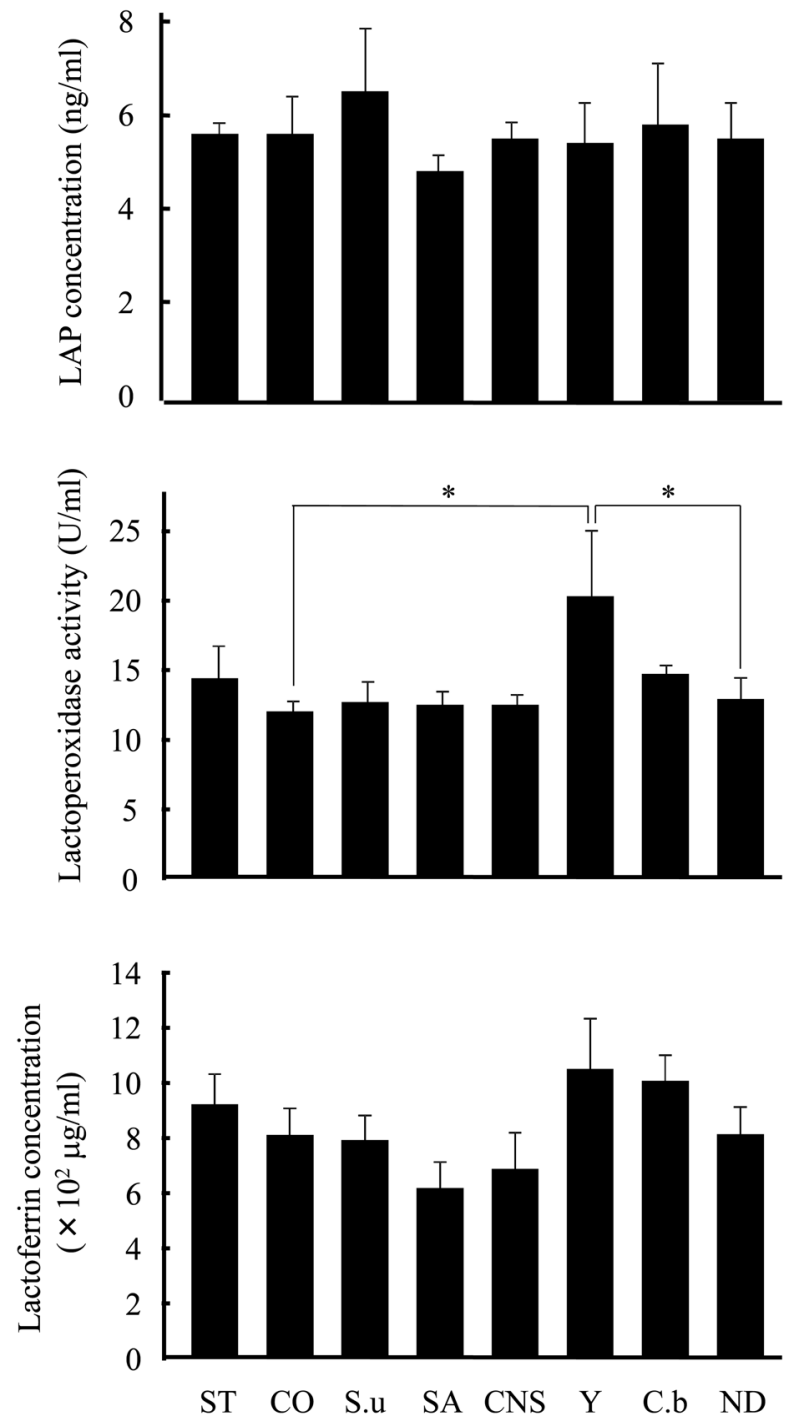

Fig. 4. Concentrations of innate immune factors (LAP, LPO and LF) in milk containing different bacteria. Bars show mean \pm $\mathrm{SD}$, and $\mathrm{n}=20,11,8,7,7,5,4$ and 15 in milk contaminated by streptococci except for $S$. agalactiae and S. uberis (ST), coliforms (CO), Streptococcus uberis (S.u.), Staphylococcus aureus (SA), coagulase-negative staphylococci (CNS), yeast (Y) and Corynebacterium bovis (C. b), and in samples in which pathogens were not detected (ND), respectively. * Significant difference $(P<0.05)$.

milk was collected and preserved at room temperature for different timespans, following which bacteriological culture examination was performed. The CFUs of ST, coliforms, CNS, yeasts and $C$. bovis decreased significantly with increasing preservation time after milk collection. These results suggest that the CFUs of some pathogens decreased during preservation of milk at room temperature.

High SCC decreased the number of yeast at $4 \mathrm{hr}$, suggesting that the decrease in these pathogens during milk preservation depends on their SCC in milk. Similarly, in SA, high SCC or LF concentration was correlated to decreased bacterial number. However, the mean CFUs of SA were not reduced during preservation. This may be attributed to the fact that some samples with high SCC and LF values showed no decrease in CFUs during preservation, resulting in no significant change in the mean CFUs. Therefore, the sensitivity of SA to antimicrobial components may depend on the microbial strains present in milk.

High SCC and LAP concentrations were correlated to the increase in CFU of CNS and C. bovis, respectively. This could be because these pathogens were killed by antibacterial factors other than those evaluated in the present study, such as tracheal antimicrobial peptide (TAP), enteric $\beta$-defensin, bovine neutrophil $\beta$-defensin (BNBD), S100 protein and cathelicidin, which have also been reported to be present in milk $[1,3,5,20,21,25]$.

In mammary glands, invading bacteria are recognized by toll-like receptors (TLRs) of leukocytes and epithelial cells, followed by the secretion of antimicrobial components into milk $[5,10,26,27]$. Thus, a high number of pathogens in the mammary glands must cause the secretion of a high amount of antibacterial components into milk. Therefore, the correlation between CFUs and the values of antibacterial components in the milk just after collection was analyzed. Significant positive correlations were observed between LF and S. uberis, SA and C. bovis, LPO and CNS, and between LAP and $C$. bovis. Since these bacteria are gram-positive, these antibacterial components were secreted by stimulation through TLR2 of leukocytes and/or epithelial cells. However, in the present study, each antibacterial component was correlated to a different kind of bacterium. Therefore, the secreted antibacterial components may depend on the bacterial species. It is reported that the concentrations of LAP, LPO and LF in milk increased by stimulation of LPS derived from gram-negative bacteria [10]. However, no correlation was observed between antimicrobial components and coliforms in the present study. Significant positive correlation was found between the CFUs of yeast and the values of LAP, LPO and LF at $0 \mathrm{hr}$. Dectin was reported to be the receptor for yeast and was localized on the cell membrane of the leukocytes and mammary epithelial cells $[2,28]$. Therefore, yeast may be recognized by these dectins, resulting in the secretion of antibacterial components into milk. LPO activity in milk infected with yeast was significantly higher than in milk infected with coliforms and NS (Fig. 4). This result may suggest that compared to bacteria, yeast stimulates more secretion of LPO through dectin receptors.

In the present study, the CFUs of ST, coliforms, CNS, yeast and $C$. bovis were decreased during milk preservation, which strongly suggests that these pathogens were phagocytosed by neutrophils and/or killed by antimicrobial components in milk. Therefore, it is suggested that cultivation of milk for pathogen identification should be started immediately after milk collection. Further studies are required to investigate the components that affect the decrease in the CFUs of pathogens during preservation.

At $0 \mathrm{hr}$, LAP concentration was positively correlated to the CFUs of yeast, whereas high LAP concentration was not correlated to a decrease in its CFU at $4 \mathrm{hr}$ and $5 \mathrm{hr}$ of preser- 
Table 3. Correlation between pathogen number in milk without culture $(0 \mathrm{hr})$ and somatic cell count (SCC), lingual antimicrobial peptide (LAP), lactoperoxidase (LPO) or lactoferrin (LF) values in milk

\begin{tabular}{lrrrl}
\hline Pathogen & SCC & LAP & LPO & LF \\
\hline ST & $0.58^{\text {b) }}$ & 0.25 & 0.27 & 0.22 \\
Coliforms & -0.32 & -0.07 & -0.14 & 0.22 \\
Streptococcus uberis & -0.03 & -0.36 & 0.35 & $0.81^{\text {b) }}$ \\
Staphylococcus aureus & 0.42 & 0.35 & 0.57 & $0.80^{\text {b) }}$ \\
Coagulase-negative staphylococci & -0.59 & 0.72 & $0.79^{\text {a) }}$ & 0.29 \\
Yeasts & -0.34 & $0.94^{\mathrm{b})}$ & $0.98^{\mathrm{b})}$ & $0.94^{\mathrm{b}}$ \\
Corynebacterium bovis & 0.07 & $0.85^{\mathrm{a})}$ & $-0.78^{\mathrm{a})}$ & $0.94^{\mathrm{b}}$ \\
\hline
\end{tabular}

Values are correlation coefficients. ST: streptococci except for $S$. agalactiae and $S$. uberis. a) $P<0.05$; b) $P<0.01$.

Table 4. Correlation between the decreasing pathogen number in milk at $4 \mathrm{hr}$ and $5 \mathrm{hr}$ of preservation and the somatic cell count (SCC), lingual antimicrobial peptide (LAP), lactoperoxidase (LPO) or lactoferrin (LF) values in milk

\begin{tabular}{|c|c|c|c|c|c|}
\hline Pathogen & $\mathrm{h}$ & $\mathrm{SCC}$ & LAP & LPO & LF \\
\hline \multirow[t]{2}{*}{ ST } & 4 & -0.13 & -0.21 & -0.02 & 0.00 \\
\hline & 5 & -0.02 & -0.02 & 0.01 & 0.05 \\
\hline \multirow[t]{2}{*}{ Coliforms } & 4 & -0.27 & -0.25 & -0.07 & 0.26 \\
\hline & 5 & -0.32 & -0.28 & -0.24 & 0.29 \\
\hline \multirow[t]{2}{*}{ Streptococcus uberis } & 4 & -0.22 & 0.50 & -0.03 & -0.47 \\
\hline & 5 & -0.25 & 0.45 & -0.14 & -0.48 \\
\hline \multirow[t]{2}{*}{ Staphylococcus aureus } & 4 & $-0.65^{\mathrm{a})}$ & 0.34 & 0.17 & $-0.61^{\mathrm{a})}$ \\
\hline & 5 & -0.46 & $0.66^{\mathrm{a})}$ & 0.05 & -0.55 \\
\hline \multirow[t]{2}{*}{ Coagulase-negative staphylococci } & 4 & $0.63^{\mathrm{a})}$ & -0.11 & -0.29 & -0.33 \\
\hline & 5 & $0.77^{\mathrm{a})}$ & -0.45 & -0.54 & -0.15 \\
\hline \multirow[t]{2}{*}{ Yeasts } & 4 & $-0.67^{\text {a) }}$ & -0.17 & -0.08 & -0.36 \\
\hline & 5 & -0.59 & -0.36 & -0.28 & -0.55 \\
\hline \multirow[t]{2}{*}{ Corynebacterium bovis } & 4 & 0.08 & $0.95^{\mathrm{b})}$ & -0.09 & 0.41 \\
\hline & 5 & -0.52 & 0.24 & 0.47 & -0.29 \\
\hline
\end{tabular}

Values are correlation coefficients. ST: streptococci except for S. agalactiae and S. uberis. a) $P<0.05$; b) $P<0.01$.

vation. This may indicate that LAP secretion was stimulated by yeast; however, LAP does not kill yeasts.

In the present study, only milk samples from cows with subclinical mastitis were used. E. coli, CNS and ST were detected, and these bacteria cause clinical mastitis. Therefore, bacterial number in the milk from clinical mastitis cows may be decreased during preservation. This remains to be elucidated.

Milk samples were preserved at 15 to $25^{\circ} \mathrm{C}$ in the present study. However, preservation at low temperature attenuates activity of antimicrobial components, which may prevent decrease of bacterial number during preservation. A further study is required to investigate the effect of various temperature for milk preservation on the changes in the bacterial number.

In conclusion, these results suggest that some pathogens in high-SCC milk decreased during preservation at room temperature, which may be associated with the presence of antimicrobial components in milk. Therefore, the reduction in microbial number in milk from the time of its collection to the time of its examination should be taken into consider- ation while evaluating its contamination.

\section{REFERENCES}

1. Boehmer, J. L., Bannerman, D. D., Shefcheck, K. and Ward, J. L. 2008. Proteomic analysis of differentially expressed proteins in bovine milk during experimentally induced Escherichia coli mastitis. J. Dairy Sci. 91: 4206-4218. [Medline] [CrossRef]

2. Bonkobara, M., Hoshino, M., Yagihara, H., Tamura, K., Isotani, M., Tanaka, Y., Washizu, T. and Ariizumi, K. 2006. Identification and gene expression of bovine C-type lectin dectin-2. Vet. Immunol. Immunopathol. 110: 179-186. [Medline] [CrossRef]

3. Diamond, G., Zasloff, M., Eck, H., Brasseur, M., Maloy, W. L. and Bevins, C. L. 1991. Tracheal antimicrobial peptide, a cysteine-richpeptide from mammalian tracheal mucosa: Peptide isolation andcloning of a cDNA. Natl. Acad. Sci. U.S.A. 88: 3952-3956.

4. Thomas, E. L. and Aune, T. M. 1978. Lactoperoxidase, peroxide, thiocyanate antimicrobial system: correlation of sulfhydryl oxidation with antimicrobial action. Infect. Immun. 20: 456-463. [Medline]

5. Goldammer, T., Zerbe, H., Molenaar, A., Schuberth, H. J., 
Brunner, R. M., Kata, S. R. and Seyfert, H. M. 2004. Mastitis increases mammary mRNA abundance of beta-defensin 5 , tolllike-receptor 2 (TLR2), and TLR4 but not TLR9 in cattle. Clin. Diagn. Lab. Immunol. 11: 174-185. [Medline]

6. Hagiwara, S., Kawai, K., Anri, A. and Nagahata, H. 2003. Lactoferrin concentrations in milk from normal and subclinical mastitic cows. J. Vet. Med. Sci. 65: 319-323. [Medline] [CrossRef]

7. Hogan, J. S., Gonzales, R. J., Harmon, R. J., Nickerson, S. C., Oliver, S. P., Pankey, J. W. and Smith, K. L. 1999. Laboratory handbook on bovine mastitis. National Mastitis Council Inc., Madison.

8. Huang, Y. Q., Morimoto, K., Hosoda, K., Yoshimura, Y. and Isobe, N. 2012. Differential immunolocalization between lingual antimicrobial peptide and lactoferrin in mammary gland of dairy cows. Vet. Immunol. Immunopathol. 145: 499-504. [Medline] [CrossRef]

9. Isobe, N., Kubota, H., Yamasaki, A. and Yoshimura, Y. 2011. Lactoperoxidase activity in milk is correlated with somatic cell count in dairy cows. J. Dairy Sci. 94: 3868-3874. [Medline] [CrossRef]

10. Isobe, N., Morimoto, K., Nakamura, J., Yamasaki, A. and Yoshimura, Y. 2009. Intramammary challenge of lipopolysaccharide stimulates secretion of lingual antimicrobial peptide into milk of dairy cows. J. Dairy Sci. 92: 6046-6051. [Medline] [CrossRef]

11. Isobe, N., Nakamura, J., Nakano, H. and Yoshimura, Y. 2009. Existence of functional lingual antimicrobial peptide in bovine milk. J. Dairy Sci. 92: 2691-2695. [Medline] [CrossRef]

12. Johansen, C., Falholt, P. and Gram, L. 1997. Enzymatic removal and disinfection of bacterial biofilms. Appl. Environ. Microbiol. 63: 3724-3728. [Medline]

13. Kawai, K., Akamatsu, H., Obayashi, T., Nagahata, H., Higuchi, H., Iwano, H., Oshida, T., Yoshimura, Y. and Isobe, N. 2013. Relationship between concentration of lingual antimicrobial peptide and somatic cell count in milk of dairy cows. Vet. Immunol. Immunopathol. 153: 298-301. [Medline] [CrossRef]

14. Komine, K., Komine, Y., Kuroishi, T., Kobayashi, J., Obara, Y. and Kumagai, K. 2005. Small molecule lactoferrin with an inflammatory effect but no apparent antibacterial activity in mastitic mammary gland secretion. J. Vet. Med. Sci. 67: 667-677. [Medline] [CrossRef]

15. Kuehn, J. S., Gorden, P. J., Munro, D., Rong, R., Dong, Q., Plummer, P. J., Wang, C. and Phillips, G. J. 2013. Bacterial community profiling of milk samples as a means to understand culture-negative bovine clinical mastitis. PLOS ONE 8: e61959. [Medline] [CrossRef]

16. Morimoto, K., Kanda, N., Shinde, S. and Isobe, N. 2012. Effect of enterotoxigenic Escherichia coli vaccine on innate immune function of bovine mammary gland infused with lipopolysaccharide. J. Dairy Sci. 95: 5067-5074. [Medline] [CrossRef]

17. Oikonomou, G., Bicalho, M. L., Meira, E., Rossi, R. E., Foditsch, C., Machado, V. S., Teixeira, A. G., Santisteban, C., Schukken,
Y. H. and Bicalho, R. C. 2014. Microbiota of cow's milk; distinguishing healthy, sub-clinically and clinically diseased quarters. PLoS ONE 9: e85904. [Medline] [CrossRef]

18. Olde Riekerink, R. G., Barkema, H. W., Kelton, D. F. and Scholl, D. T. 2008. Incidence rate of clinical mastitis on Canadian dairy farms. J. Dairy Sci. 91: 1366-1377. [Medline] [CrossRef]

19. Östensson, K., Lam, V., Sjögren, N. and Wredle, E. 2013. Prevalence of subclinical mastitis and isolated udder pathogens in dairy cows in Southern Vietnam. Trop. Anim. Health Prod. 45: 979-986. [Medline] [CrossRef]

20. Regenhard, P., Leippe, M., Schubert, S., Podschun, R., Kalm, E., Grötzinger, J. and Looft, C. 2009. Antimicrobial activity of bovine psoriasin. Vet. Microbiol. 136: 335-340. [Medline] [CrossRef]

21. Selsted, M. E., Tang, Y. Q., Morris, W. L., McGuire, P. A., Novotny, M. J., Smith, W., Henschen, A. H. and Cullor, J. S. 1993. Purification, primary structures, and antibacterial activities of $\beta$-defensins, a new family of antimicrobial peptides from bovine neutrophils. J. Biol. Chem. 268: 6641-6648. [Medline]

22. Schonwetter, B. S., Stolzenberg, E. D. and Zasloff, M. A. 1995. Epithelial antibiotics induced at sites of inflammation. Science 267: 1645-1648. [Medline] [CrossRef]

23. Shin, K., Hayasawa, H. and Lönnerdal, B. 2001. Inhibition of Escherichia coli respiratory enzymes by the lactoperoxidasehydrogen peroxide-thiocyanate antimicrobial system. J. Appl. Microbiol. 90: 489-493. [Medline] [CrossRef]

24. Swanson, K., Gorodetsky, S., Good, L., Davis, S., Musgrave, D., Stelwagen, K., Farr, V. and Molenaar, A. 2004. Expression of a $\beta$-defensin mRNA, lingual antimicrobial peptide, in bovine mammary epithelial tissue is induced by mastitis. Infect. Immun. 72: 7311-7314. [Medline] [CrossRef]

25. Tarver, A. P., Clark, D. P., Diamond, G., Russell, J. P., Erdjument-Bromage, H., Tempst, P., Cohen, K. S., Jones, D. E., Sweeney, R. W., Wines, M., Hwang, S. and Bevins, C. L. 1998. Enteric $\beta$-defensin: molecular cloning and characterization of a gene with inducible intestinal epithelial cell expression associated with Cryptosporidium parvum infection. Infect. Immun. 66 : 1045-1056. [Medline]

26. Zhang, G. W., Lai, S. J., Yoshimura, Y. and Isobe, N. 2014. Expression of cathelicidins mRNA in the goat mammary gland and effect of the intramammary infusion of lipopolysaccharide on milk cathelicidin-2 concentration. Vet. Microbiol. 170: 125-134. [Medline] [CrossRef]

27. Zhang, G. W., Lai, S. J., Yoshimura, Y. and Isobe, N. 2014. Messenger RNA expression and immunolocalization of psoriasin in the goat mammary gland and its milk concentration after an intramammary infusion of lipopolysaccharide. Vet. J. 202: 89-93. [Medline] [CrossRef]

28. Willcocks, S., Yamakawa, Y., Stalker, A., Coffey, T. J., Goldammer, T. and Werling, D. 2006. Identification and gene expression of the bovine C-type lectin Dectin-1. Vet. Immunol. Immunopathol. 113: 234-242. [Medline] [CrossRef] 